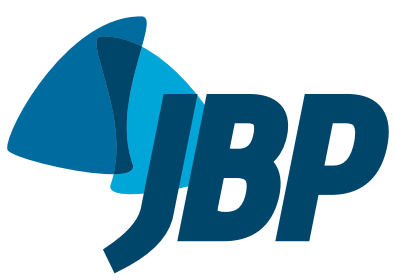

1. Faculdade de Medicina, Universidade Federal de Goiás, Goiânia (GO) Brasil.

2. Centro Universitário de Anápolis, Anápolis (GO) Brasil.

3. Pontifícia Universidade Católica de Goiás, Goiânia (GO) Brasil.

4. Faculdade de Medicina de Petrópolis, Petrópolis (RJ) Brasil.

5. Faculdade de Medicina, Universidade Federal do Rio de Janeiro,

Rio de Janeiro (RJ) Brasil.

Submitted: 21 December 2016

Accepted: 4 May 2017

Study carried out at the Faculdade de Medicina, Universidade Federal de Goiás, Goiânia (GO) Brasil.

\title{
Tuberculosis treatment
}

Marcelo Fouad Rabahii ${ }^{1,2}$, José Laerte Rodrigues da Silva Júnior², Anna Carolina Galvão Ferreira ${ }^{1,3}$, Daniela Graner Schuwartz Tannus-Silva ${ }^{1}$, Marcus Barreto Conde ${ }^{4,5}$

\section{INTRODUCTION}

Tuberculosis treatment is aimed at curing and rapidly reducing disease transmission. For this to occur, the drugs used should be able to reduce the bacillary population rapidly (interrupting transmission); prevent selection of naturally resistant strains (avoiding the emergence of drug resistance during therapy); and sterilize the lesion (preventing disease relapse). ${ }^{(1)}$

Although antituberculosis regimens have an efficacy of up to $95 \%$, treatment effectiveness (patients who are cured at the end of treatment under routine conditions) varies greatly with location, with the national average being around $70 \%$ (50-90\%). One of the causes of low effectiveness is nonadherence, which can occur at three levels $\boldsymbol{s}^{(2,3)}$ :

- treatment default (patients stop using all medications) or

- incorrect medication use (patients use some of the prescribed medications) and/or

- irregular medication use (patients take the medications some days of the week but not every day of the week)

Treatment adherence problems are responsible both for treatment failure and for selection of resistant organisms and disease relapse. In order to improve adherence to tuberculosis treatment and restructure health care facilities, the World Health Organization (WHO) has, since the early 1990s, recommended the adoption of the directly observed treatment, short course (DOTS) strategy. The DOTS strategy includes five elements ${ }^{(4,5)}$ :

1. Political commitment and financial support to maintain tuberculosis control activities
2. Identification of tuberculosis cases on the basis of sputum smear microscopy among patients with respiratory symptoms

3. A standardized antituberculosis drug regimen administered as directly observed treatment (DOT) for at least the first 2 months of treatment

4. Guarantee of a regular supply of antituberculosis drugs

5 A system for reporting and assessment of treatment results for each patient and for the tuberculosis control program as a whole

Although supervised medication-taking through DOT allows frequent contact between patients and the health care system and favors treatment adherence, systematic reviews have failed to demonstrate greater effectiveness of DOT compared with self-administered treatment. ${ }^{(6-8)}$ This probably occurs because treatment effectiveness is in fact related to several factors (Chart 1) and not only to medication-taking, which is a variable related to patient care.

Nevertheless, DOT remains the standard practice of most tuberculosis control programs in the USA and Europe, since it appears to be significantly associated with sputum smear conversion (from positive to negative) during treatment. As a result, DOT is recommended in both Europe and the USA for all forms of tuberculosis. In 1998, the Programa Nacional de Controle da Tuberculose (PNCT, Brazilian National Tuberculosis Control Program) implemented DOT in Brazil, and, since 2000, measures of decentralization have been taken, including integration of tuberculosis control into primary health care and the proposal to provide DOT at $100 \%$ of the health care clinics in the priority cities and for at least $80 \%$ of patients with active tuberculosis in those cities; however, this has not 
Chart 1. Factors that influence the effectiveness of tuberculosis treatment.

\section{PATIENT-RELATED FACTORS}

Age, comorbidities, immune status, nutritional status, abusive alcohol intake, adherence to treatment, and drug tolerance

Genetic characteristics affecting drug absorption and metabolism, and individual vulnerability to toxicities

FACTORS RELATED TO THE ORGANISM/DISEASE PRESENTATION

Virulence of the organism

Susceptibility of the strain

Radiological extent of the disease and presence of cavities

CARE-RELATED FACTORS

Motivational capacity of the staff, access of patients to the health care system, and monitoring and supervision of patients regarding treatment

\section{TREATMENT-RELATED FACTORS}

Amount of each drug administered, plasma concentrations of administered drugs; relationship between administered drugs and proteins, clearance, metabolism, and absorption

Drug bioavailability of the presentations (single-drug tablets, fixed-dose combination tablets), and drug interactions with other drugs

Treatment regimen used (daily or intermittent), which influences duration and frequency of drug administration; bactericidal and sterilizing potency; and drug synergy or antagonism

occurred. It should be borne in mind that most of the countries that use DOT offer intermittent (non-daily) treatment, as is the case in Brazil. $(1,2,9,10)$

There are situations in which self-administered treatment cannot be used, however, and, in such cases, all efforts should be made toward DOT. Such cases include patients with drug-resistant tuberculosis or at high risk of developing drug resistance (individuals without a fixed home; drinkers; users of illicit drugs; individuals who cannot take medications on their own because of mental, emotional, or physical impairment; children and adolescents; individuals deprived of their liberty; and individuals with a history of nonadherence to treatment). ${ }^{(11,12)}$

\section{TUBERCULOSIS AND THE BRAZILIAN} NATIONAL HEALTH CARE SYSTEM

Reporting of tuberculosis is mandatory in Brazil. The report form should record patient identification data, place of origin of the case, clinical form of the disease, and comorbidities. In addition, tuberculosis case type should be indicated on the form (field 32 : type of admission). Below are the definitions of the types of admission for tuberculosis cases used in the Brazilian Case Registry Database. A new case is defined as one in which the individual has never received antituberculosis treatment or received it for up to 30 days. A retreatment case or a case of readmission after default is defined as one in which the individual was treated for more than 30 days and requires additional treatment because of relapse after cure or return after default. A relapse case is defined in the PNCT manual (2011) as one in which the individual with active tuberculosis has been previously treated and cured, regardless of the time elapsed since the previous treatment. In tuberculosis relapse cases, it is mandatory to request sputum culture and drug susceptibility testing for Mycobacterium tuberculosis, and the possibility of resistance to antituberculosis drugs should be ruled out. Until culture and drug susceptibility testing results are available, treatment with the basic regimen should be initiated. This working definition does not include relapse due to lack of sterilization of a lesion of exogenous reinfection, a piece of information that might be relevant in the assessment of the efficacy and effectiveness of both the treatment and the tuberculosis control program. Studies conducted in Africa, Europe, and the USA suggest that most relapse cases occurring two years after cure are due to reinfection and not to relapse. In fact, a certain diagnosis of relapse of tuberculosis would be made regardless of length of discharge as cured and would be based on the identification of the same $M$. tuberculosis cluster by a molecular biology technique (fingerprinting). However, in Brazil, fingerprinting is available only in research laboratories and in some private laboratories. Field 32 (type of admission) also includes the following options: "transfer"; "post-death"; and "unknown." The term "transfer" is used to refer to the admission of patients coming from another city, and this type of admission can produce changes in tuberculosis indicators, since these data are excluded from the calculation of the rates of diagnosis and treatment outcomes, such as treatment default. The same applies to the terms "unknown" and "post-death". Therefore, in Brazil, there is uncertainty regarding the representativeness of the tuberculosis indicators presented by the PNCT.

Antituberculosis drugs are provided free of charge, this being guaranteed by the PNCT, and they are not commercially available. These drugs are widely available in the public health care system, but they are dispensed to patients only upon presentation of a completed report form. The responsibility of completing the report form lies with the health care worker who makes the diagnosis of tuberculosis and prescribes the medication. ${ }^{(1,10,13,14)}$ 


\section{TUBERCULOSIS TREATMENT}

\section{Tuberculosis treatment in adults}

In the 1940s, the Brazilian National Campaign against Tuberculosis was started, and, during that period, two antituberculosis drugs were used: streptomycin and para-aminosalicylic acid. In the 1950s, Brazil chose to use a twice-weekly regimen with isoniazid and streptomycin. In the 1960s, given bacterial resistance and the increase in mortality from tuberculosis, treatment regimens began to be standardized, and the use of isoniazid $(H)$, streptomycin $(S)$, and pyrazinamide ( $Z$ ) for 18 months (HSZ regimen) was implemented. ${ }^{(15,16)}$ In the mid 1970s, short-term antituberculosis chemotherapy, with rifampin (R), isoniazid $(\mathrm{H})$, and pyrazinamide $(\mathrm{Z})$ for 6 months ( $\mathrm{RHZ}$ regimen), was developed. Brazil was the first country in the world to implement the 6-month regimen in the public health care system, with all drugs being administered p.o. and being distributed free of charge. In the 1980s, combination capsules of $\mathrm{RH}$ were implemented already aiming to prevent acquired bacterial resistance. In 2009, Brazil introduced the use of fixed-dose combination (FDC) tablets and added ethambutol ( $E$ ) to the $\mathrm{RHZ}$ regimen, as defined by the PNCT, on the basis of the preliminary results of the Second National Survey on Antituberculosis Drug Resistance, which showed an increase in primary resistance to isoniazid (from $4.4 \%$ to $6.0 \%$ ). In addition, besides the change in presentation to FDC, the doses of isoniazid and pyrazinamide in the tablets were reduced in the treatment change (from $400 \mathrm{mg}$ to $300 \mathrm{mg}$ and from $2,000 \mathrm{mg}$ to $1,600 \mathrm{mg}$, respectively), without bioavailability or bioequivalence studies being carried out. The basic regimen currently used in Brazil for the treatment of adults with tuberculosis and without clinical suspicion of drug resistance is presented in Chart 2. It consists of a 2-month intensive phase with the FDC RHZE regimen, followed by a 4-month maintenance phase with the FDC $\mathrm{RH}$ regimen, and it is used for all forms of the disease in patients over 10 years of age. The exception is patients with meningitis due to tuberculosis, who, in the maintenance phase, are treated for 7 months and with the combination of an oral corticosteroid (prednisone, at a dose of
1-2 $\mathrm{mg} / \mathrm{kg} /$ day for 4 weeks) or an i.v. corticosteroid (dexamethasone, at a dose of $0.3-0.4 \mathrm{mg} / \mathrm{kg} / \mathrm{day}$ for 4-8 weeks). ${ }^{(10,15,16)}$ The medications are available in FDC tablets. Each tablet contains $150 \mathrm{mg}$ of rifampin, $75 \mathrm{mg}$ of isoniazid, $400 \mathrm{mg}$ of pyrazinamide, and 275 $\mathrm{mg}$ of ethambutol.

As defined in the PNCT handbook on tuberculosis, ${ }^{(10)}$ the second phase of treatment can be extended for 7 months, after consultation with a referral center, in the following cases:

- Patients with HIV/AIDS

- Patients whose direct smears show few organisms at 5 or 6 months of treatment, alone, as long as there is clinical and radiological improvement-treatment can be extended for an additional 3 months, at which period cases should be redefined or closed

- Patients with negative direct smears and an unsatisfactory clinical and radiological course

- Patients with cavitary forms who remain smear-positive at the end of the second month of treatment-in such cases, culture and drug susceptibility testing are mandatory

- Patients with monoresistance to rifampin or isoniazid, identified in the maintenance phase of treatment-a careful assessment of the clinical, bacteriological, and radiological course, as well as of adherence and previous tuberculosis treatment, should be performed at or under the guidance of a tertiary referral center

According to the literature, individuals at the highest risk of relapse of tuberculosis (due to lack of sterilization of the lesion) include those whose weight is less than $10 \%$ of the ideal weight and whose weight gain is less than or equal to $5 \%$ in the intensive phase of treatment; smokers; and patients with insulin-dependent diabetes, HIV infection, or another immunosuppressive condition. For such individuals, extension of the maintenance phase of treatment should be considered. In addition, in patients who had cavitation (total diameter $\geq 2 \mathrm{~cm}$ ) on the initial chest $X$-ray and are culture positive for $M$. tuberculosis at the end of the first 8 weeks of treatment (completion of the intensive phase of treatment), the maintenance phase of treatment can be extended for an additional 3 months because of the increased risk of relapse. Unfortunately, only $15-20 \%$ of the cases

Chart 2. Treatment regimen for all new cases of all forms of pulmonary and extrapulmonary tuberculosis (except meningoencephalitis), as well as for all cases of relapse and return after default. ${ }^{a}$

\begin{tabular}{|c|c|c|c|}
\hline Regimen $^{b}$ & Drugs (mg/tablet) ${ }^{c}$ & Body weight, kg & Dose \\
\hline 2RHZE & RHZE & $\leq 20$ & $10 / 10 / 35 / 25 \mathrm{mg} / \mathrm{kg} / \mathrm{day}$ \\
\hline \multirow[t]{3}{*}{ Intensive phase } & $(150 / 75 / 400 / 275)$ & 20- 35 & 2 tablets \\
\hline & & $36-50$ & 3 tablets \\
\hline & & $>50$ & 4 tablets \\
\hline $4 \mathrm{RH}$ & $\mathrm{RH}$ & $\leq 20$ & $10 / 10 \mathrm{mg} / \mathrm{kg} /$ day \\
\hline \multirow[t]{3}{*}{ Maintenance phase } & $(150 / 75)$ & $20-35$ & 2 tablets \\
\hline & & $36-50$ & 3 tablets \\
\hline & & $>50$ & 4 tablets \\
\hline
\end{tabular}

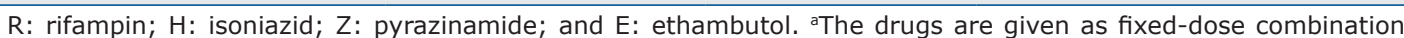
tablets. ${ }^{\mathrm{D}}$ The number preceding the acronym indicates duration of treatment in months. 'The dose of each drug in $\mathrm{mg}$ in each tablet is listed below its corresponding letter in the acronym. 
of pulmonary tuberculosis in Brazil undergo sputum culture and drug susceptibility testing..$^{(1,17-23)}$

In cases in which it is impossible to use the basic regimen because of intolerance to two or more drugs, the use of a regimen for multidrug-resistant tuberculosis (MDR-TB) is indicated (Chart 3). In instances of treatment failure (as defined by the PNCT: individuals who remain sputum smear-positive at the end of treatment; individuals who are ++ or +++ smear positive and remain so until the fourth month of treatment; and those with initial smear-positivity followed by smear-negativity and then smear-positivity again for 2 consecutive months, from the fourth month of treatment onward), the use of the basic regimen should be extended until culture and drug susceptibility testing results are available. The possibility of nontuberculous mycobacterial infection should be considered, as should medication dosage error, irregular medication use, and inadequate drug absorption. The bioavailability of the drugs used in the treatment of tuberculosis (except rifapentine) is increased when they are taken on an empty stomach (the bioavailability of rifapentine increases by up to $86 \%$ with high-fat meals). If the medications need to be taken with foods or liquids, glucose-rich or lactose-rich foods should be avoided, since glucose and lactose reduce the absorption of isoniazid. Few drug interactions can cause substantial changes in the concentrations of medications for tuberculosis treatment; however, medications for tuberculosis treatment often cause clinically relevant changes in the concentrations of other drugs. ${ }^{(1,10,24,25)}$

\section{Tuberculosis treatment in children}

In Brazil, patients under 10 years of age are treated with three medications: rifampin $(10 \mathrm{mg} / \mathrm{kg})$, isoniazid (10 mg/kg), and pyrazinamide $(35 \mathrm{mg} / \mathrm{kg})$. This decision is based on the lower risk of resistance to isoniazid in patients with a low bacterial load, as is more common in children with tuberculosis, and on the risk of ethambutol-related visual impairment, the diagnosis of which can be difficult in children. $(24,26,27)$

On the basis of systematic reviews of the literature, the American Academy of Pediatrics ${ }^{(27)}$ recommends the four-drug treatment, with the addition of ethambutol, in the intensive phase of treatment, along with monitoring of visual acuity and of the ability to discriminate between red and green colors. In cases of children whose visual acuity cannot be monitored, the risk-benefit ratio of the use of ethambutol should be considered, observing that ethambutol can be routinely used to treat active tuberculosis in infants and children unless there is some other contraindication. (27) The WHO recommends that HIV-negative children with pulmonary tuberculosis who live in areas with a low prevalence of HIV infection and a low prevalence of resistance to isoniazid can be treated with three drugs ( $\mathrm{RHZ}$ regimen) in the induction phase, without the addition of ethambutol. In cases of children who live in areas with a high prevalence of HIV infection and/or a high prevalence of resistance to isoniazid, ethambutol should be added to the regimen in the induction phase. ${ }^{(27,28)}$

\section{Tuberculosis treatment: approaches in cases of treatment interruption}

Occasionally, patients interrupt drug therapy during treatment. Chart 4 presents the management of such cases in each of six circumstances. ${ }^{(1)}$

\section{Tuberculosis treatment outcomes}

Reporting of treatment completion (outcome) is obligatory in the same way as reporting of tuberculosis cases for treatment initiation. Below are the definitions of treatment outcome. Cure is defined as a negative sputum smear or culture in the last month of treatment and at least once previously, in cases of tuberculosis confirmed bacteriologically at the start of treatment. Failure is defined as a positive sputum smear or culture at 5 months or later during treatment. Default is defined as tuberculosis treatment interruption of $\geq 30$ days after the predicted date of return (self-administered treatment) or of 30 days after the last drug intake (DOT; for management of treatment interruptions, see Chart 4). A death from tuberculosis is defined as a death caused by tuberculosis and occurring during treatment. A death from another cause is defined as a death from a cause other than tuberculosis and occurring during treatment. ${ }^{(10,29)}$

\section{DRUG-RESISTANT TUBERCULOSIS}

Cases of drug-resistant tuberculosis are classified according to the susceptibility of $M$. tuberculosis to first- and second-line drugs used in the pharmacological treatment of this disease. Below are the definitions of the main terms used in communication about cases of drug-resistant tuberculosis. Monodrug-resistant tuberculosis is defined as tuberculosis caused by organisms resistant to one first-line antituberculosis drug. Polydrug-resistant TB is defined as tuberculosis caused by organisms resistant to more than one first-line antituberculosis drug (except isoniazid and rifampin, resistance to both of which is characterized as multidrug resistance). MDR-TB is defined as tuberculosis caused by organisms resistant to both isoniazid and rifampin. Extensively drug-resistant tuberculosis is defined as tuberculosis caused by organisms resistant to rifampin, isoniazid, a fluoroquinolone, and at least one of three injectable second-line drugs (amikacin, kanamycin, or capreomycin). Rifampin-resistant tuberculosis is defined as tuberculosis caused by organisms identified as having resistance to rifampin by rapid molecular testing for tuberculosis drug resistance (with it being possible that there are other resistances still unknown, since a large proportion of cases identified as having resistance to rifampin also have resistance to isoniazid). $(29,30)$

In addition to the classification of tuberculosis based on the susceptibility of organisms to drugs, mycobacterial resistance can be classified as primary or acquired. Primary resistance occurs in tuberculosis caused by 
Chart 3. Treatment of multidrug-resistant and extensively drug-resistant tuberculosis.

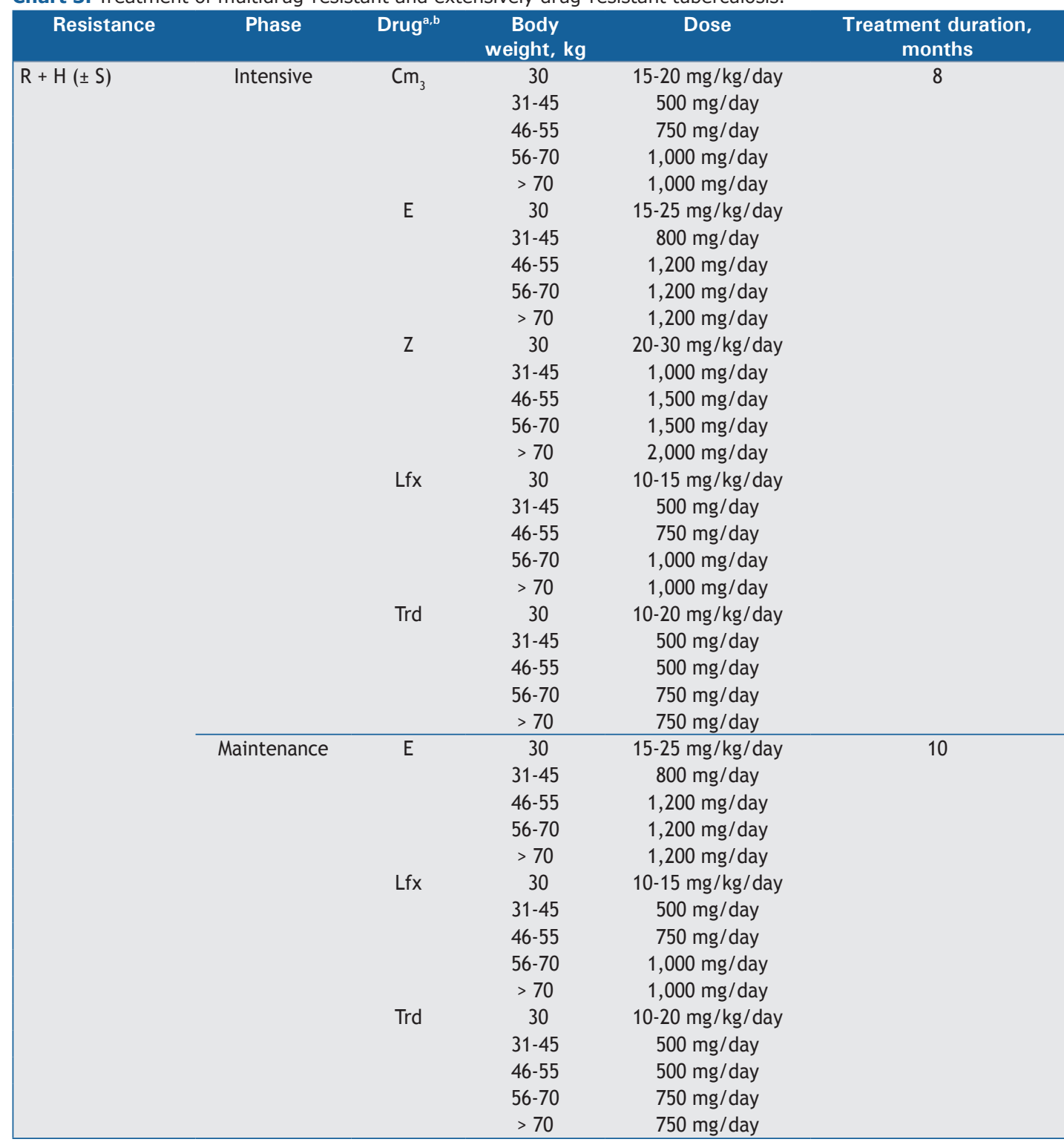

R: rifampin; H: isoniazid; S: streptomycin; Cm: capreomycin; E: ethambutol; Z: pyrazinamide; Lfx: levofloxacin; Trd: terizidone; and Et: ethionamide. aThe subscript number after a drug abbreviation indicates the number of days per week that the drug will be used; if there is no subscript number, treatment with that drug is daily. ${ }^{\text {bIn patients }}$ who have already used capreomycin, use amikacin as an alternative. In patients who do not have resistance to streptomycin as determined by drug susceptibility testing and who have not used amikacin, amikacin can also be considered for use. Doses of amikacin and streptomycin: up to $30 \mathrm{~kg}, 15-20 \mathrm{mg} / \mathrm{kg} / \mathrm{day}$; from 31 to $45 \mathrm{~kg}, 500$ $\mathrm{mg} /$ day; from 46 to $55 \mathrm{~kg}, 750 \mathrm{mg} /$ day; $\geq 56 \mathrm{~kg}, 1,000 \mathrm{mg} / \mathrm{day}$.

a bacillary population that is primarily resistant to an antituberculosis drug. In such cases, the individuals have never used an antituberculosis drug and are infected with an already resistant strain, presumably transmitted by a case of acquired resistance. Acquired resistance is that which occurs in a bacillary population that is initially susceptible to antituberculosis drugs and subsequently acquires resistance to some of them. Since the frequency of spontaneous mutations is low and since the use of an appropriate combination of drugs in the pharmacological treatment of tuberculosis makes the occurrence of clinically significant resistance unlikely, this type of resistance is presumably the result of irregular or inadequate treatment. ${ }^{(1)}$

\section{Drug-resistant tuberculosis treatment}

Drug-resistant tuberculosis treatment depends on the type of resistance identified. The approaches in cases of monoresistance and polyresistance are described in Chart 5.

The presence of multidrug resistance (resistance to $\mathrm{RH}$ or to RH and another first-line drug) is an indication for the use of the MDR-TB treatment regimen. The MDR-TB treatment regimen (Chart 3 ) has been changed by 
Chart 3. Continued...

\begin{tabular}{|c|c|c|c|c|c|}
\hline Resistance & Phase & Drug $^{a, b}$ & $\begin{array}{c}\text { Body } \\
\text { weight, kg }\end{array}$ & Dose & $\begin{array}{c}\text { Treatment duration, } \\
\text { months }\end{array}$ \\
\hline $\begin{array}{l}R+H+E( \pm S) \text { or } \\
R+H+E+Z( \pm S)\end{array}$ & Intensive & . & $\begin{array}{c}30 \\
31-45 \\
46-55 \\
56-70 \\
>70 \\
30 \\
31-45 \\
46-55 \\
56-70 \\
>70 \\
30 \\
31-45 \\
46-55 \\
56-70 \\
>70 \\
30 \\
31-45 \\
46-55 \\
56-70 \\
>70 \\
30 \\
31-45 \\
46-55 \\
56-70 \\
>70\end{array}$ & $\begin{array}{c}15-20 \mathrm{mg} / \mathrm{kg} / \text { day } \\
500 \mathrm{mg} / \text { day } \\
750 \mathrm{mg} / \text { day } \\
1,000 \mathrm{mg} / \text { day } \\
1,000 \mathrm{mg} / \text { day } \\
15-20 \mathrm{mg} / \mathrm{kg} / \text { day } \\
500 \mathrm{mg} / \text { day } \\
750 \mathrm{mg} / \text { day } \\
750 \mathrm{mg} / \text { day } \\
750 \mathrm{mg} / \text { day } \\
20-30 \mathrm{mg} / \mathrm{kg} / \text { day } \\
1,000 \mathrm{mg} / \text { day } \\
1,500 \mathrm{mg} / \text { day } \\
1,500 \mathrm{mg} / \text { day } \\
2,000 \mathrm{mg} / \text { day } \\
10-15 \mathrm{mg} / \mathrm{kg} / \text { day } \\
500 \mathrm{mg} / \text { day } \\
750 \mathrm{mg} / \text { day } \\
1,000 \mathrm{mg} / \text { day } \\
1,000 \mathrm{mg} / \text { day } \\
10-20 \mathrm{mg} / \mathrm{kg} / \text { day } \\
500 \mathrm{mg} / \text { day } \\
500 \mathrm{mg} / \text { day } \\
750 \mathrm{mg} / \text { day } \\
750 \mathrm{mg} / \text { day }\end{array}$ & 8 \\
\hline & Maintenance & Lfx & $\begin{array}{c}30 \\
31-45 \\
46-55 \\
56-70 \\
>70 \\
30 \\
31-45 \\
46-55 \\
56-70 \\
>70 \\
30 \\
31-45 \\
46-55 \\
56-70 \\
>70\end{array}$ & $\begin{array}{c}15-20 \mathrm{mg} / \mathrm{kg} / \text { day } \\
500 \mathrm{mg} / \text { day } \\
750 \mathrm{mg} / \text { day } \\
750 \mathrm{mg} / \text { day } \\
750 \mathrm{mg} / \text { day } \\
10-15 \mathrm{mg} / \mathrm{kg} / \text { day } \\
500 \mathrm{mg} / \text { day } \\
750 \mathrm{mg} / \text { day } \\
1,000 \mathrm{mg} / \text { day } \\
1,000 \mathrm{mg} / \text { day } \\
10-20 \mathrm{mg} / \mathrm{kg} / \text { day } \\
500 \mathrm{mg} / \text { day } \\
500 \mathrm{mg} / \text { day } \\
750 \mathrm{mg} / \text { day } \\
750 \mathrm{mg} / \text { day }\end{array}$ & 10 \\
\hline
\end{tabular}

R: rifampin; H: isoniazid; S: streptomycin; Cm: capreomycin; E: ethambutol; Z: pyrazinamide; Lfx: levofloxacin; Trd: terizidone; and Et: ethionamide. aThe subscript number after a drug abbreviation indicates the number of days per week that the drug will be used; if there is no subscript number, treatment with that drug is daily. ${ }^{\text {bIn }}$ patients who have already used capreomycin, use amikacin as an alternative. In patients who do not have resistance to streptomycin as determined by drug susceptibility testing and who have not used amikacin, amikacin can also be considered for use. Doses of amikacin and streptomycin: up to $30 \mathrm{~kg}, 15-20 \mathrm{mg} / \mathrm{kg} / \mathrm{day}$; from 31 to $45 \mathrm{~kg}, 500$ $\mathrm{mg} /$ day; from 46 to $55 \mathrm{~kg}, 750 \mathrm{mg} /$ day; $\geq 56 \mathrm{~kg}, 1,000 \mathrm{mg} /$ day.

including capreomycin (as the injectable drug of choice because it results in fewer side effects and less crossresistance with other injectable drugs); by replacing ethambutol with ethionamide when drug susceptibility testing shows resistance to ethambutol; and by using levofloxacin (in accordance with the recommendations of the WHO). Note that pyrazinamide should always be used in the intensive phase of treatment, even when drug susceptibility testing shows resistance, since there are limitations to interpreting such results (do not use pyrazinamide only in cases of hepatotoxicity or severe adverse effects). ${ }^{(30)}$
In cases of rifampin-resistant tuberculosis as determined by a rapid molecular test for tuberculosis drug resistance, initiate treatment with the recommended regimen (Chart 4 ) and wait until drug susceptibility testing results are available. If drug susceptibility testing shows susceptibility to all drugs, assess the risk of resistance on a case-by-case basis. In low-risk patients, start the basic regimen, which should be administered for 6 months, regardless of duration of MDR-TB regimen use. In high-risk patients (for example, retreatment cases, contacts of MRD-TB patients, or alcohol and drug users), maintain the MDR-TB regimen. 
Chart 3. Continued...

\begin{tabular}{|c|c|c|c|c|c|}
\hline Resistance & Phase & Druga,b $^{a, b}$ & $\begin{array}{c}\text { Body } \\
\text { weight, kg }\end{array}$ & Dose & $\begin{array}{c}\text { Treatment duration, } \\
\text { months }\end{array}$ \\
\hline $\mathrm{R}+\mathrm{H}+\mathrm{Z}( \pm \mathrm{S})$ & Intensive & Et & $\begin{array}{c}30 \\
31-45 \\
46-55 \\
56-70 \\
>70 \\
30 \\
31-45 \\
46-55 \\
56-70 \\
>70 \\
30 \\
31-45 \\
46-55 \\
56-70 \\
>70 \\
30 \\
31-45 \\
46-55 \\
56-70 \\
>70 \\
30 \\
31-45 \\
46-55 \\
56-70 \\
>70 \\
30 \\
31-45 \\
46-55 \\
56-70 \\
>70\end{array}$ & $\begin{array}{c}15-20 \mathrm{mg} / \mathrm{kg} / \text { day } \\
500 \mathrm{mg} / \text { day } \\
750 \mathrm{mg} / \text { day } \\
1,000 \mathrm{mg} / \text { day } \\
1,000 \mathrm{mg} / \text { day } \\
15-25 \mathrm{mg} / \mathrm{kg} / \text { day } \\
800 \mathrm{mg} / \text { day } \\
1,200 \mathrm{mg} / \text { day } \\
1,200 \mathrm{mg} / \text { day } \\
1,200 \mathrm{mg} / \text { day } \\
20-30 \mathrm{mg} / \mathrm{kg} / \text { day } \\
1,000 \mathrm{mg} / \text { day } \\
1,500 \mathrm{mg} / \text { day } \\
1,500 \mathrm{mg} / \text { day } \\
2,000 \mathrm{mg} / \text { day } \\
10-15 \mathrm{mg} / \mathrm{kg} / \text { day } \\
500 \mathrm{mg} / \text { day } \\
750 \mathrm{mg} / \text { day } \\
1,000 \mathrm{mg} / \text { day } \\
1,000 \mathrm{mg} / \text { day } \\
15-20 \mathrm{mg} / \mathrm{kg} / \text { day } \\
500 \mathrm{mg} / \text { day } \\
750 \mathrm{mg} / \text { day } \\
750 \mathrm{mg} / \text { day } \\
750 \mathrm{mg} / \text { day } \\
10-20 \mathrm{mg} / \mathrm{kg} / \text { day } \\
500 \mathrm{mg} / \text { day } \\
500 \mathrm{mg} / \text { day } \\
750 \mathrm{mg} / \text { day } \\
750 \mathrm{mg} / \text { day }\end{array}$ & 8 \\
\hline & Maintenance & Trd & $\begin{array}{c}30 \\
31-45 \\
46-55 \\
56-70 \\
>70 \\
30 \\
31-45 \\
46-55 \\
56-70 \\
>70 \\
30 \\
31-45 \\
46-55 \\
56-70 \\
>70 \\
30 \\
31-45 \\
46-55 \\
56-70 \\
>70 \\
\end{array}$ & $\begin{array}{c}15-25 \mathrm{mg} / \mathrm{kg} / \text { day } \\
800 \mathrm{mg} / \text { day } \\
1,200 \mathrm{mg} / \text { day } \\
1,200 \mathrm{mg} / \text { day } \\
1,200 \mathrm{mg} / \text { day } \\
10-15 \mathrm{mg} / \mathrm{kg} / \text { day } \\
500 \mathrm{mg} / \text { day } \\
750 \mathrm{mg} / \text { day } \\
1,000 \mathrm{mg} / \text { day } \\
1,000 \mathrm{mg} / \text { day } \\
15-20 \mathrm{mg} / \mathrm{kg} / \text { day } \\
500 \mathrm{mg} / \text { day } \\
750 \mathrm{mg} / \text { day } \\
750 \mathrm{mg} / \text { day } \\
750 \mathrm{mg} / \text { day } \\
10-20 \mathrm{mg} / \mathrm{kg} / \text { day } \\
500 \mathrm{mg} / \text { day } \\
500 \mathrm{mg} / \text { day } \\
750 \mathrm{mg} / \text { day } \\
750 \mathrm{mg} / \text { day }\end{array}$ & 10 \\
\hline
\end{tabular}

$\mathrm{R}$ : rifampin; $\mathrm{H}$ : isoniazid; S: streptomycin; Cm: capreomycin; $\mathrm{E}$ : ethambutol; Z: pyrazinamide; Lfx: levofloxacin; Trd: terizidone; and Et: ethionamide. ${ }^{a}$ The subscript number after a drug abbreviation indicates the number of days per week that the drug will be used; if there is no subscript number, treatment with that drug is daily. ${ }^{\text {bIn patients }}$ who have already used capreomycin, use amikacin as an alternative. In patients who do not have resistance to streptomycin as determined by drug susceptibility testing and who have not used amikacin, amikacin can also be considered for use. Doses of amikacin and streptomycin: up to $30 \mathrm{~kg}, 15-20 \mathrm{mg} / \mathrm{kg} / \mathrm{day}$; from 31 to $45 \mathrm{~kg}, 500$ $\mathrm{mg} /$ day; from 46 to $55 \mathrm{~kg}, 750 \mathrm{mg} /$ day; $\geq 56 \mathrm{~kg}, 1,000 \mathrm{mg} /$ day.

In patients who have already used capreomycin, use amikacin as an alternative in those who do not have resistance to streptomycin as determined by drug susceptibility testing and who have not used amikacin; 
Chart 4. Management of treatment interruptions.

\begin{tabular}{|c|c|c|}
\hline Interruption time point & Details of interruption & Approach \\
\hline \multirow[t]{2}{*}{ During the intensive phase } & Lapse is $<14$ days in duration & $\begin{array}{l}\text { Continue treatment to complete the } \\
\text { planned total number of doses ( } 60 \text { doses), } \\
\text { as long as the intensive phase lasts } 3 \\
\text { months at most }\end{array}$ \\
\hline & Lapse is $\geq 14$ days in duration & Restart treatment from the beginning \\
\hline \multirow[t]{4}{*}{ During the maintenance phase } & $\begin{array}{l}\text { Received } \geq 80 \% \text { of the doses and was } \\
\text { smear-negative }^{b}\end{array}$ & $\begin{array}{l}\text { Continue treatment. The patient may not } \\
\text { need to take all doses }\end{array}$ \\
\hline & $\begin{array}{l}\text { Received } \geq 80 \% \text { of the doses and } \\
\text { was smear-positive at the start of } \\
\text { treatment }\end{array}$ & $\begin{array}{l}\text { Continue treatment until all } 120 \text { doses are } \\
\text { completed }\end{array}$ \\
\hline & $\begin{array}{l}\text { Received }<80 \% \text { of the doses, and } \\
\text { accumulative lapse is }<3 \text { months in } \\
\text { duration }\end{array}$ & $\begin{array}{l}\text { Continue treatment until all } 120 \text { doses } \\
\text { are completed, unless consecutive lapse } \\
\text { is }>2 \text { months in duration. In such cases, } \\
\text { restart treatment. If treatment cannot } \\
\text { be completed within } 9 \text { months (with the } \\
\text { intensive phase lasting } 3 \text { months at most } \\
\text { and the maintenance phase lasting } 6 \\
\text { months at most), restart treatment from } \\
\text { the beginning of the intensive phase. }\end{array}$ \\
\hline & $\begin{array}{l}\text { Received }<80 \% \text { of the doses, and } \\
\text { accumulative lapse is } \geq 3 \text { months in } \\
\text { duration }\end{array}$ & $\begin{array}{l}\text { Restart treatment from the beginning (new } \\
\text { intensive and maintenance phases) }\end{array}$ \\
\hline
\end{tabular}

aSmear microscopy, culture, and susceptibility testing should always be performed when patients resume treatment. bSmear-negative patient: a patient with at least two AFB-negative sputum samples (including one sample collected in the morning); X-ray findings consistent with tuberculosis and/or no clinical response to treatment with broadspectrum antimicrobial agents (Note: fluoroquinolones should not be used because they have activity against the Mycobacterium tuberculosis complex and can produce transient improvement in patients with tuberculosis); satisfactory response to antituberculosis treatment.

Chart 5. Treatment of monodrug-resistant and polydrug-resistant tuberculosis.

\begin{tabular}{|c|c|c|}
\hline \multirow[t]{2}{*}{ Resistance to } & \multicolumn{2}{|c|}{ Regimen $^{a}$} \\
\hline & Intensive phase & Maintenance phase \\
\hline $\mathrm{H}$ & 2RZES & $4 \mathrm{RE}^{(10)}$ \\
\hline $\mathrm{R}$ & $6 \mathrm{~S}_{3} \mathrm{HZELfx}$ & $6 \mathrm{HELfX}^{(30)}$ \\
\hline R (identified by rapid molecular testing) ${ }^{\mathrm{b}}$ & $8 \mathrm{Cm}_{3}$ EZLfxTrd & 10ELfxTrd \\
\hline $\mathrm{H}+\mathrm{Z}^{\mathrm{c}}$ & 2RESO & 7REO \\
\hline$H+E^{c}$ & 2RZSO & 7RO \\
\hline$R+Z$ & $8 \mathrm{HCm}_{3}$ EZLfxTrd & 10HELfXTrd ${ }^{(30)}$ \\
\hline$R+E$ & $8 \mathrm{Cm}_{3}$ EtZLfxTrd & 10HEtLfxTrd ${ }^{(30)}$ \\
\hline$H+Z+E$ & $3 \mathrm{RSOT}^{\mathrm{d}}$ & $12 \mathrm{ROT}^{(10)}$ \\
\hline
\end{tabular}

$\mathrm{H}$ : isoniazid; R: rifampin; Z: pyrazinamide; $\mathrm{E}$ : ethambutol; S: streptomycin; Lfx: levofloxacin; Cm: capreomycin; Trd: terizidone; O: ofloxacin; and Et: ethionamide. ${ }^{a}$ The number preceding the acronym indicates duration of treatment in weeks. The subscript number after a drug abbreviation indicates the number of days per week that the drug should be used; if there is no subscript number, treatment with that drug is daily. ${ }^{\text {bIf }}$ there is monoresistance to $R$ and the patient has been on the $8 \mathrm{Cm}_{3}$ EZLfXTrd/10ELfXTrd regimen for more than 1 month, continue the regimen until completion; if the patient has been on that regimen for less than 1 month, discontinue it and start the $6 \mathrm{~S}_{3} \mathrm{HZELfx} / 6 \mathrm{HELfx}$ regimen. If susceptibility testing shows multidrug resistance $(\mathrm{R}+\mathrm{H}$ or $\mathrm{R}+\mathrm{H}+$ resistance to any other first-line drugs), see Chart 3 . If susceptibility testing shows polyresistance $(R+$ resistance to first-line drugs other than $\mathrm{H}$ ), continue the regimen for R-resistant tuberculosis with the addition of $\mathrm{H}: 8 \mathrm{HCm}_{3}$ EZLfxTrd/10 HLfxTrd (Chart 4). ${ }^{(30)}$ cOptionally replace $O$ with Lfx. ${ }^{(10)}$ dExtend the intensive phase for 6 months in cases of extensive bilateral disease. ${ }^{(10)}$

amikacin can be considered for use in patients with a history of previous treatment. Assess each case individually on the basis of medications used and drug susceptibility testing results. ${ }^{(30)}$

Treatment of extensively drug-resistant tuberculosis (Chart 3) should be carried out at a tertiary health care facility, specializing in the treatment of drug-resistant tuberculosis. Individualized regimens and salvage drugs are used.(24)

\section{Adverse reactions to tuberculosis treatment}

The most frequent adverse reactions to the RHZE regimen are a change in urine color (it occurs universally), gastric intolerance (in $40 \%$ of patients), skin changes (in 20\%), jaundice (in 15\%), and joint pain (in $4 \%$ ). The major associated factors are age (from the fourth decade of life onward), alcohol dependence (daily alcohol intake $>80 \mathrm{~g}$ ), malnutrition (loss of more than $15 \%$ of body weight), history of liver disease, 
Chart 6. Adverse reactions and approach. ${ }^{a}$

\begin{tabular}{|c|c|c|}
\hline Adverse reactions & Probable causative drug & Approach \\
\hline \multicolumn{3}{|l|}{ Minor } \\
\hline $\begin{array}{l}\text { Anorexia, vomiting, nausea, abdominal } \\
\text { pain }\end{array}$ & $\mathrm{R}, \mathrm{H}, \mathrm{Z}$ & $\begin{array}{l}\text { Advise patients to take the antituberculosis } \\
\text { drugs at the appropriate time, prescribe } \\
\text { symptomatic treatment, and reassess the } \\
\text { need for requesting the determination of } \\
\text { hepatic enzyme levels. }\end{array}$ \\
\hline Orange- or red-colored sweat/urine & $\mathrm{R}$ & Instruct patients. \\
\hline Pruritus & $S, R$ & Prescribe antihistamines. \\
\hline Joint pain & Z & Prescribe aspirin. \\
\hline Paresthesia & H (common) or E (uncommon) & Prescribe pyridoxine (50 mg/day). \\
\hline Asymptomatic hyperuricemia & Z & Prescribe follow-up/diet. \\
\hline Hyperuricemia and arthralgia & $\mathrm{E}$ & $\begin{array}{l}\text { Prescribe follow-up/diet/symptomatic } \\
\text { treatment. }\end{array}$ \\
\hline Arthritis/arthralgia & $\mathrm{H}, \mathrm{Z}$ & Prescribe symptomatic treatment. \\
\hline Headache, anxiety, euphoria, insomnia & $\mathrm{H}$ & Instruct patients. \\
\hline \multicolumn{3}{|l|}{ Major } \\
\hline Exanthema/pruritus & $\mathrm{S}, \mathrm{R}$ & $\begin{array}{l}\text { Discontinue the drugs and reintroduce one } \\
\text { drug at a time. }\end{array}$ \\
\hline $\begin{array}{l}\text { Fever, oliguria, exanthema (interstitial } \\
\text { nephritis, rhabdomyolysis) }\end{array}$ & Z & Discontinue $\mathrm{Z}$. Use the $2 \mathrm{RHE} / 7 \mathrm{RH}$ regimen. \\
\hline Hypoacusis & $\mathrm{S}$ & $\begin{array}{l}\text { Replace } S \text { with } E \text { (maintain the planned } \\
\text { duration of the regimen). }\end{array}$ \\
\hline Vertigo/nystagmus & S & $\begin{array}{l}\text { Replace } S \text { with } E \text { (maintain the planned } \\
\text { duration of the regimen). }\end{array}$ \\
\hline Convulsive seizures, encephalopathy & $\mathrm{H}$ & Use the 2 RZES 5 /7RE regimen. \\
\hline $\begin{array}{l}\text { Vomiting and mental confusion } \\
\text { (prehepatic jaundice?) }\end{array}$ & Any drug $(H, R, Z, E, S, E t)$ & $\begin{array}{l}\text { Discontinue the regimen and request the } \\
\text { determination of hepatic enzyme levels. } \\
\text { If ALT is abnormal, follow a regimen for } \\
\text { managing hepatotocixity. }{ }^{\mathrm{b}}\end{array}$ \\
\hline $\begin{array}{l}\text { Jaundice (if other causes have been } \\
\text { ruled out) }\end{array}$ & Any drug $(H, R, Z, E, S$, Et) & $\begin{array}{l}\text { Discontinue the regimen and request the } \\
\text { determination of hepatic enzyme levels. } \\
\text { If ALT is abnormal, follow a regimen for } \\
\text { managing hepatotoxicity. }\end{array}$ \\
\hline $\begin{array}{l}\text { Optic neuritis (loss of side vision, change } \\
\text { in color vision) }\end{array}$ & $\begin{array}{l}\text { E (common) and } \mathrm{H} \\
\text { (uncommon) }\end{array}$ & Use the $2 \mathrm{RHZ} / 4 \mathrm{RH}$ or $2 \mathrm{RZES}_{5} / 7 \mathrm{RE}$ regimen. \\
\hline Shock, purpura & $\mathrm{R}$ & Use the $2 \mathrm{HZES}_{5} / 10 \mathrm{HE}$ regimen. \\
\hline
\end{tabular}

Adapted from Conde et al.,(24) Maciel et al., ${ }^{(32)}$ and Ferreira et al. ${ }^{(33)} \mathrm{R}$ : rifampin; H: isoniazid; Z: pyrazinamide; $\mathrm{E}$ : ethambutol; S: streptomycin; Et: ethionamide; and ALT: alanine aminotransferase. ${ }^{a}$ The number preceding the acronym indicates duration of treatment in weeks. The subscript number after a drug abbreviation indicates the number of days per week that the drug should be used; if there is no subscript number, treatment with that drug is daily. "See "Tuberculosis and liver disease."

and HIV coinfection. Chart 6 presents the suggested approaches to major adverse reactions; it is important to note that, when an adverse reaction results from a hypersensitivity reaction (thrombocytopenia, hemolytic anemia, or renal failure), the suspected drug should not be restarted after discontinuation, since the adverse reaction upon reintroduction is even more intense and severe. $(10,24,31,32)$

In two observational studies conducted in Brazil, $(32,33)$ the frequency of adverse reactions to the use of the RHZE regimen was found to be $47.5 \%$ and $83.4 \%$, respectively, which is higher than that historically seen in the medical literature; however, there were no severe reactions or the need for treatment discontinuation. The most common adverse reactions were joint pain and gastric reactions, followed by skin reactions. ${ }^{(32,33)}$

\section{TUBERCULOSIS AND LIVER DISEASE}

The risk of hepatitis induced by drugs used in tuberculosis treatment is increased in patients with liver disease, especially in those with advanced liver disease, those undergoing liver transplantation, and those with hepatitis $\mathrm{C}$, and therefore it is necessary to monitor transaminases-alanine aminotransferase (ALT) and aspartate aminotransferase (AST)-and bilirubin every 1-4 weeks in the first 2-3 months. ${ }^{(1)}$ In patients with chronic, stable liver disease who are asymptomatic, do not have cirrhosis, and have ALT levels $\leq 3$ times the upper limit of normal (ULN), the basic regimen can be used unchanged; in those with ALT levels $>3$ times the ULN, the RHE regimen should be used for 2 months in the intensive phase and $\mathrm{RH}$ should be used for 7 months in the maintenance phase. ${ }^{(34,35)}$ In symptomatic chronic liver disease with 
ALT levels $>3$ times the ULN, the following regimens can be used: HRES for 2 months followed by HE for 6 months; HRE for 2 months followed by HE for 6 months; HSE for 2 months followed by HE for 10 months; or $\mathrm{SE}+$ ofloxacin (O) for 3 months followed by EO for 9 months. In patients with cirrhosis, the regimen with the least hepatotoxic potential is used: $\mathrm{RE}+\mathrm{a}$ fluoroquinolone or ofloxacin or cycloserine, for 12-18 months. In cases of acute hepatitis, an attempt should be made to defer tuberculosis treatment initiation until hepatitis resolves. If this is not possible, prescribe the SE regimen for 3 months followed by RH for 6 months or the SEO regimen for 3 months followed by $\mathrm{RH}$ for 6 months (in extensive tuberculosis) and ofloxacin (400 mg/day) once daily in the morning, regardless of body weight. $(1,10,11,24,27,34-40)$

A transient increase in ALT/AST may occur during the first weeks of treatment, being of no clinical significance. Treatment should be discontinued only if there is anorexia, malaise, and vomiting and the ALT level is > 3 times the ULN or when the ALT level is > 3 times the ULN, even in the absence of symptoms, if jaundice is present. In cases of hepatotoxicity induced by tuberculosis treatment and ALT $>5$ times the ULN, even in the absence of symptoms, treatment should also be discontinued. $(1,10,24)$

After discontinuation of tuberculosis treatment, investigate alcohol abuse and use of other hepatotoxic medications. Every patient with a history of alcoholism and being treated for tuberculosis should receive pyridoxine ( $50 \mathrm{mg} /$ day) to prevent peripheral neuritis. In severe cases, until the cause of the abnormality is identified, or in cases in which transaminase and/or bilirubin levels do not return to normal after 4 weeks off treatment, use the SEO regimen for 3 months followed by EO for 9 months, with or without the addition of isoniazid. Given the efficacy of isoniazid and, especially, of rifampin, their use should always be attempted, even in the presence of preexisting liver injury. $(1,10,24)$

In cases of hepatotoxicity caused by tuberculosis treatment, the medication can be restarted when the ALT level is $<2$ times the ULN. Reintroduction should occur gradually, with one drug at a time. First rifampin, with or without ethambutol; after 3-7 days, reassess the ALT level: if there is no increase, restart the use of isoniazid 1 week after the introduction of rifampin and restart the use of pyrazinamide 1 week after the introduction of isoniazid. If ALT levels increase or if symptoms recur, discontinue the last medication added. In patients experiencing prolonged or severe hepatotoxicity (ALT > 10 times the ULN), do not use pyrazinamide; use the RHE regimen for 2 months followed by RH for 7 months. $(1,10,24)$

\section{TUBERCULOSIS AND DIABETES}

In insulin-dependent patients, it is suggested that the RHZE regimen be extended for 9 months. In non-insulindependent patients, the regimen remains unchanged, with attention being given to the prophylactic use of pyridoxine and the possible need for the use of insulin during tuberculosis treatment. $(1,10,21,24)$

\section{TUBERCULOSIS AND IMMUNOSUPPRESSION}

In cases of tuberculosis/HIV coinfection, initiation of antiretroviral therapy (ART) should be based on the degree of immunosuppression; in cases of patients whose CD4 counts are below 50 cells $/ \mathrm{mm}^{3}$, ART should be initiated 2 weeks after initiation of antituberculosis treatment, and, in other cases, ART should be initiated only after the eighth week of treatment. When tuberculosis is diagnosed in patients already receiving ART, it may be necessary to change ART to allow the addition of rifampin to therapy, and, in such cases, efavirenz is the antiretroviral of choice. Replacing rifampin with rifabutin is recommended when it is necessary to combine a protease inhibitor with ritonavir in the ART regimen. The recommended dose of rifabutin is $150 \mathrm{mg} /$ day in such cases. The most frequent adverse reactions to rifabutin are exanthema (in 4\%), gastrointestinal intolerance (in 3\%), and neutropenia (in $2 \%)^{(1,23)}$

Immune reconstitution inflammatory syndrome is not an indication for discontinuation of any treatment. Its management includes the use of medications for treating symptoms and corticosteroids in cases that are more severe.

Transplant recipients should be treated at referral centers, with the RHZE regimen for 2 months followed by $\mathrm{RH}$ for 4 months, and treatment can be extended for up to 9 months. Attention should be given to possible drug interactions with corticosteroids, cyclosporine, and azathioprine. ${ }^{(1,23,35)}$

\section{TUBERCULOSIS AND PREGNANCY}

During pregnancy, the RHZE regimen can be administered at the usual doses, and concurrent use of pyridoxine ( $50 \mathrm{mg} /$ day) is recommended because of the risk of newborns having convulsive seizures. Although the medications in the RHZE regimen cross the placental barrier, they do not appear to be teratogens. Regarding breastfeeding, although the medications are present in breast milk in small amounts, there is no risk of toxicity to newborns nor is there any prophylactic effect. $(10,24,40)$

\section{TUBERCULOSIS AND RENAL FAILURE}

Tuberculosis patients with renal failure have poorer outcomes than do those with normal renal function and should be assessed more often. Rifampin and isoniazid are metabolized in the liver and do not require dose adjustment. Pyrazinamide is also metabolized in the liver, but its metabolite may accumulate in patients with renal failure, as may ethambutol, since its metabolism occurs mainly $(80 \%)$ in the kidneys; therefore, for 
these two medications, the recommended use is 3 times a week. ${ }^{(41,42)}$

Another recommendation is that the medications be administered after a hemodialysis session, since, although the hemodialysis session cannot eliminate rifampin, it efficiently removes pyrazinamide metabolites and partially removes isoniazid and ethambutol. The influence of peritoneal dialysis on the concentrations of antituberculosis drugs is unknown, and the recommendations for hemodialysis patients should not be applied to peritoneal dialysis patients; however, attention should be given to possible toxicity. ${ }^{(1)}$

The safest regimen in renal failure is $\mathrm{RHZ}$ for 2 months followed by $\mathrm{RH}$ for 4 months (creatinine clearance between $30-50 \mathrm{~mL} / \mathrm{min}$ ). The treatment is changed in renal failure patients with creatinine clearance $<30 \mathrm{~mL} /$ min or undergoing dialysis (administer after dialysis). In such patients, use isoniazid at a dose of $300 \mathrm{mg} /$ day or $900 \mathrm{mg} 3$ times a week; rifampin at a dose of $600 \mathrm{mg} /$ day or $600 \mathrm{mg}$ per administration 3 times a week; pyrazinamide at a dose of $25-35 \mathrm{mg} / \mathrm{kg}$ per administration 3 times a week (do not administer daily); ethambutol at a dose of $20-25 \mathrm{mg} / \mathrm{kg}$ per administration 3 times a week (do not administer daily); levofloxacin at a dose of $750-1,000 \mathrm{mg} / \mathrm{kg}$ per administration 3 times a week (do not administer daily); moxifloxacin at a dose of $400 \mathrm{mg}$ daily; ethionamide at a dose of 250-500 mg/kg per administration daily; streptomycin at a dose of $15 \mathrm{mg} / \mathrm{kg}$ per administration 2-3 times a week (do not administer daily); and amikacin at dose of $15 \mathrm{mg} / \mathrm{kg}$ per administration 2-3 times a week (do not administer daily). ${ }^{(1)}$

\section{SURGICAL TREATMENT OF TUBERCULOSIS}

Although tuberculosis is treated by using medications, occasionally, it may even be treated surgically in specific cases, especially in cases of drug resistance and in some pulmonary tuberculosis complications. Surgical lung biopsy has application in the differential diagnosis of pulmonary tuberculosis and lung cancer. The indications for surgical treatment include mainly endobronchial tuberculosis, as well as severe adverse reactions, severe hemoptysis, empyema, pneumothorax, and bronchopleural fistula. In tuberculosis sequelae, surgical interventions may be required in cases of symptomatic pulmonary residue, fungus ball, and hemoptysis. ${ }^{(24)}$

\section{LATENT TUBERCULOSIS INFECTION (LTBI)}

LTBI is defined as the presence of a specific immune response to $M$. tuberculosis in the absence of clinical signs of disease. The number of viable organisms in such cases is unknown, but it is believed to be low. The lifetime risk of reactivation tuberculosis in individuals with documented LTBI is $5-10 \%$, and most develop the disease in the first 5 years after the initial infection. However, this risk depends on several factors, the most important of which is the immune status of the individual. In Brazil, the estimated number of individuals infected with M. tuberculosis is $\mathbf{5 0}$ million, which represents a challenge for tuberculosis control in the country. One of the tuberculosis control strategies is the reduction of this large reservoir of individuals infected with $M$. tuberculosis who are at risk of progression to active disease. ${ }^{(3,43-45)}$

\section{Assessment of patients on anti-TNF-a therapy and immunosuppressive therapy}

TNF-a plays a central role in granuloma formation, and, since anti-TNF-a agents began to be used, the reported incidence rate of tuberculosis has increased, many of such cases being cases of extrapulmonary tuberculosis and usually occurring during the first six infusions. Therefore, every patient who is a candidate for TNF-a blocker therapy should be assessed for LTBI (epidemiology, chest imaging, and specific immunity to M. tuberculosis). Tuberculin skin testing (TST) and IFN-y release assays are adversely affected by several immunosuppressive drugs commonly used by this group of patients, and uncertainty persists as to the screening test of choice. Until better evidence is available, both seem feasible for the diagnosis. TST results $\geq 5 \mathrm{~mm}^{(10)}$ or positive IFN-y release assays indicate the need for LTBI treatment, which should be instituted for at least 30 days before the initiation of anti-TNF-a therapy. When it is not possible to carry out TST, take epidemiological risk and imaging tests into special account and assess each case individually in terms of risk/benefit. Chest CT can bring additional information because it is more sensitive than chest $X$-ray in detecting lesions suggestive of LTBI. ${ }^{(20,46-51)}$

Corticosteroid therapy with doses equivalent to 15 $\mathrm{mg} /$ day of prednisone for more than 1 month is an indication for LTBI treatment if TST results are $\geq 5 \mathrm{~mm}$ in individuals under 65 years of age. In individuals aged 65 years or older, the increased risk of hepatotoxicity would be a limitation for this indication. In dialysis patients, the risk of reactivation tuberculosis is at least 10 times higher than in the general population. A TST result $\geq 10 \mathrm{~mm}$ appears to identify patients at increased risk of developing the disease and is an indication for LTBI treatment. It is estimated that $25-30 \%$ of patients with silicosis will develop tuberculosis. LTBI treatment is recommended if TST results are $\geq 10 \mathrm{~mm} \cdot{ }^{(10,52,53)}$

\section{LTBI treatment}

LTBI is treated with isoniazid at a dose of $5-10 \mathrm{mg} / \mathrm{kg}$ of body weight up to a maximum of $300 \mathrm{mg} /$ day for 6 months or with isoniazid $(900 \mathrm{mg}$ ) plus rifapentine (900 $\mathrm{mg}$ ) once a week for 3 months, and LTBI cases should be reported using a specific form. The risk of hepatitis with either regimen is very low, and monitoring of hepatic aminotransferase levels during LTBI treatment is recommended only in individuals with liver disease or with risk factors for liver disease. In individuals who do not tolerate isoniazid, an alternative treatment is the use of rifampin for 4 months. $(10,43,54)$ 
Chart 7. Infectious Diseases Society of America/Centers for Disease Control and Prevention/American Thoracic Society joint recommendations, based on PICO (an acronym based on questions regarding the Patients of interest, Intervention being studied, Comparison of the intervention, and Outcome of interest) questions and on the Grading of Recommendations Assessment, Development, and Evaluation approach and endorsed by the European Respiratory Society.

\section{Question}

1. Does adding case management interventions to curative therapy improve outcomes compared with curative therapy alone among patients with tuberculosis? (Case management is defined as patient education/counseling, home visits, integration/coordination of care with specialists and general practitioners, patient reminders, and use of incentives/enablers)

2. Does self-administered therapy have similar results compared with directly observed therapy in patients with various forms of tuberculosis?

3. Does intermittent dosing in the intensive phase have similar outcomes compared with daily dosing in the intensive phase for treatment of drug-susceptible pulmonary tuberculosis?

4. Does intermittent dosing in the maintenance phase have similar outcomes compared with daily dosing in the maintenance phase in patients with drug-susceptible pulmonary tuberculosis?

\section{Does extending treatment} beyond 6 months improve outcomes compared with the standard 6-month treatment regimen among pulmonary tuberculosis patients coinfected with HIV?

\section{Recommendation}

1. We suggest using case management interventions during treatment of patients with tuberculosis. (Conditional recommendation; very low certainty in the evidence)

2. We suggest using directly observed therapy rather than self-administered therapy for routine treatment of all forms of tuberculosis. (Conditional recommendation; low certainty in the evidence)

$3 a$. We recommend the use of daily rather than intermittent dosing in the intensive phase of therapy for drug susceptible pulmonary tuberculosis.

(Strong recommendation; moderate certainty in the evidence))

3b. Use of thrice-weekly directly observed therapy in the intensive phase (with or without an initial 2 weeks of daily therapy) may be considered in patients who are not HIV-infected and are at low risk of relapse (pulmonary tuberculosis caused by drug-susceptible organisms, which at the start of treatment is non-cavitary and/or smear negative). (Conditional recommendation; low certainty in the evidence)

3c. In situations in which daily or thrice-weekly directly observed therapy is difficult to achieve, use of twice-weekly therapy after an initial 2 weeks of daily therapy may be considered for patients who are not HIV-infected and are at low risk of relapse (pulmonary tuberculosis caused by drug-susceptible organisms, which at the start of treatment is non-cavitary and/or smear negative). (Conditional recommendation; very low certainty in the evidence) Note: If doses are missed in a regimen using twice-weekly dosing, then therapy is equivalent to once weekly, which is inferior (See Question 4). 4 a. We recommend the use of daily or thrice-weekly dosing in the maintenance phase of therapy for drug-susceptible pulmonary tuberculosis. (Strong recommendation; moderate certainty in the evidence) $4 \mathrm{~b}$. If intermittent therapy is to be administered in the maintenance phase, we suggest use of thrice-weekly instead of twice-weekly therapy. (Conditional recommendation; low certainty in the evidence)

This recommendation allows for the possibility that if some doses are missed, treatment is still adequate. In contrast, with twice-weekly therapy, if doses are missed, then therapy is equivalent to once weekly, which is inferior. 4c. We recommend against use of once-weekly therapy with isoniazid $900 \mathrm{mg}$ and rifapentine $600 \mathrm{mg}$ in the maintenance phase. (Strong recommendation; high certainty in the evidence)

In uncommon situations in which more than once-weekly directly observed therapy is difficult to achieve, once-weekly maintenance phase therapy with isoniazid $900 \mathrm{mg}$ and rifapentine $600 \mathrm{mg}$ may be considered for use only in HIV-uninfected individuals without cavitation on chest X-ray.

5a. For HIV-infected individuals receiving antiretroviral therapy, we recommend using the standard 6-month daily regimen consisting of an intensive phase of 2 months of isoniazid, rifampin, pyrazinamide, and ethambutol followed by a maintenance phase of 4 months of rifampin and isoniazid for the treatment of drug-susceptible pulmonary tuberculosis. (Conditional recommendation; very low certainty in the evidence) 5b. In uncommon situations in which HIV-infected individuals do not receive antiretroviral therapy during tuberculosis treatment, we recommend extending the maintenance phase with isoniazid and rifampin for an additional 3 months (i.e., a maintenance phase corresponding to a total of 9 months of treatment) for the treatment of drug-susceptible pulmonary tuberculosis. (Conditional recommendation; very low certainty in the evidence) 
Chart 7. Continued...

\begin{tabular}{|c|c|}
\hline Question & Recommendation \\
\hline $\begin{array}{l}\text { 6. Does initiation of antiretroviral } \\
\text { therapy during tuberculosis } \\
\text { treatment compared with at the end } \\
\text { of tuberculosis treatment improve } \\
\text { outcomes among tuberculosis } \\
\text { patients coinfected with HIV? }\end{array}$ & $\begin{array}{l}\text { 6. We recommend initiating antiretroviral therapy during tuberculosis } \\
\text { treatment. Antiretroviral therapy should ideally be initiated within the first } \\
2 \text { weeks of tuberculosis treatment for individuals with CD4 counts }<50 \text { cells/ } \\
\mu \mathrm{L} \text { and by } 8-12 \text { weeks of tuberculosis treatment initiation for individuals with } \\
\text { CD4 counts } \geq 50 \text { cells/ } \mu \mathrm{L} \text {. (Strong recommendation; high certainty in the } \\
\text { evidence) } \\
\text { Note: An exception is individuals with HIV infection and tuberculous } \\
\text { meningitis, in whom antiretroviral therapy is not initiated in the first } 8 \text { weeks } \\
\text { of tuberculosis treatment. }\end{array}$ \\
\hline $\begin{array}{l}\text { 7. Does the use of adjuvant } \\
\text { corticosteroids in tuberculous } \\
\text { pericarditis provide mortality and } \\
\text { morbidity benefits? }\end{array}$ & $\begin{array}{l}\text { 7. We recommend that adjunctive corticosteroid therapy not be } \\
\text { routinely used in individuals with tuberculous pericarditis. (Conditional } \\
\text { recommendation; very low certainly in the evidence) }\end{array}$ \\
\hline $\begin{array}{l}\text { 8. Does the use of adjuvant } \\
\text { corticosteroids in tuberculous } \\
\text { meningitis provide mortality and } \\
\text { morbidity benefits? }\end{array}$ & $\begin{array}{l}\text { 8. We recommend adjunctive corticosteroid therapy with dexamethasone } \\
\text { or prednisolone tapered over 6-8 weeks for individuals with tuberculous } \\
\text { meningitis. (Strong recommendation; moderate certainty in the evidence) }\end{array}$ \\
\hline $\begin{array}{l}\text { 9. Does a shorter duration of } \\
\text { treatment have similar outcomes } \\
\text { compared with the standard } \\
\text { 6-month treatment duration among } \\
\text { HIV-uninfected individuals with } \\
\text { paucibacillary tuberculosis (i.e., } \\
\text { sputum smear negative, culture } \\
\text { negative)? }\end{array}$ & $\begin{array}{l}\text { 9. We suggest that a 4-month treatment regimen is adequate for treatment } \\
\text { of HIV-uninfected adults with sputum smear-negative, culture-negative } \\
\text { pulmonary tuberculosis. (Conditional recommendation; very low certainly in } \\
\text { the evidence) }\end{array}$ \\
\hline
\end{tabular}

Adapted from Sotgiu et al. ${ }^{(1)}$ and Nahid et al.(2)

There is as yet no clear evidence to guide the choice of drugs for LTBI treatment in contacts of index cases that are known to be drug-resistant. Logic indicates that contacts of MDR-TB cases should be treated with drugs to which the organisms are susceptible. The decision regarding optimal treatment should be made at the referral center where the index case is followed. The WHO suggests that contacts should be carefully monitored for the development of active tuberculosis for 2 years instead of being treated for LTBI. ${ }^{(10,44)}$

A recent study demonstrated that 3-month administration, once a week, of a combination of isoniazid and rifapentine for LTBI treatment is safe and has efficacy similar to that of monotherapy with isoniazid in children aged 2-17 years. However, the small number of children under 5 years of age and of children infected with HIV limits the generalization of the study results in these important risk groups. ${ }^{(55,56)}$

\section{NEW TREATMENTS FOR DRUG- SUSCEPTIBLE TUBERCULOSIS AND DRUG- RESISTANT TUBERCULOSIS}

New drugs and new combinations of already known drugs have been tested in tuberculosis treatment with the aims of reducing treatment duration and increasing treatment effectiveness in cases of drugsusceptible tuberculosis and in cases of MDR-TB. After five decades without new drugs for tuberculosis treatment, bedaquiline (TMC-207) and delamanid (OPC-67683) have been approved by the US Food and Drug Administration for use in clinical practice. These two drugs are basically indicated for MDR-TB.
Since 2009, clinical studies have demonstrated that the use of fluoroquinolones, especially moxifloxacin, in combination with other antituberculosis drugs, $\mathrm{RHZ}$ and rifapentine, significantly increases the rate of $M$. tuberculosis culture conversion in the eighth week of treatment, suggesting the possibility of treatment shortening. In a systematic review of clinical trials of fluoroquinolones versus ethambutol, which was published in 2016, the results showed that it was possible to reduce treatment to 4 months, while maintaining the same effectiveness in patients with noncavitary pulmonary tuberculosis and a positive culture; however, the results in clinical practice remain controversial. ${ }^{(57-59)}$

\section{New scientific evidence}

A recent joint publication by the Infectious Diseases Society of America, the Centers for Disease Control and Prevention, and the American Thoracic Society ${ }^{(2)}$ presented tuberculosis treatment recommendations based on scientific evidence obtained by using the Grading of Recommendations, Assessment, Development and Evaluations (GRADE; Chart 7) approach, ${ }^{(60)}$ all of which have been endorsed by the European Respiratory Society. ${ }^{(1)}$ GRADE is a systematic approach that assesses quality of evidence and strength of scientific recommendations. The GRADE approach has been developed by the GRADE working group and is seen as the most effective method of assessing quality of evidence and clinical recommendations.

In comparing the PNCT recommendations with the new scientific evidence, we can see that some 
points can be assessed with a view to future revised PNCT recommendations, such as adopting supervised intermittent treatment in the second phase of treatment and not using corticosteroids in tuberculous pericarditis. ${ }^{(1)}$

\section{REFERENCES}

1. Sotgiu G, Nahid P, Loddenkemper R, Abubakar I, Miravitlles M, Migliori GB. The ERS-endorsed official ATS/CDC/IDSA clinical practice guidelines on treatment of drug-susceptible tuberculosis. Eur Respir J. 2016;48(4):963-71. https://doi.org/10.1183/13993003.01356-2016

2. Nahid P, Dorman SE, Alipanah N, Barry PM, Brozek JL, Cattamanchi A, et al. Executive Summary: Official American Thoracic Society/ Centers for Disease Control and Prevention/Infectious Diseases Society of America Clinical Practice Guidelines: Treatment of DrugSusceptible Tuberculosis. Clin Infect Dis. 2016;63(7):853-67. https:// doi.org/10.1093/cid/ciw566

3. TB CARE I. International Standards for Tuberculosis Care Edition 3. The Hague: TB CARE I; 2014

4. Parida A, Bairy KL, Chogtu B, Magazine R, Vidyasagar S. Comparison of Comparison of Directly Observed Treatment Short Course (DOTS) with Self-Administered Therapy in Pulmonary Tuberculosis in Udupi District of Southern India. J Clin Diagn Res. 2014;8(8):HC29-31.

5. Lienhardt C, Ogden JA. Tuberculosis control in resource-poor countries: have we reached the limits of the universal paradigm? Trop Med Int Health. 2004;9(7):833-41. https://doi.org/10.1111/ j.1365-3156.2004.01273.x

6. Seaworth BJ, Armitige LY, Griffith DE. First do no harm--adverse events, drug intolerance, and hepatotoxicity: how can we not justify directly observed therapy for treating tuberculosis? Clin Infect Dis. 2013;57(7):1063-4. https://doi.org/10.1093/cid/cit432

7. Pasipanodya JG, Gumbo T. A meta-analysis of self-administered vs directly observed therapy effect on microbiologic failure, relapse, and acquired drug resistance in tuberculosis patients. Clin Infect Dis. 2013;57(1):21-31. https://doi.org/10.1093/cid/cit167

8. Karumbi J, Garner P. Directly observed therapy for treating tuberculosis. Cochrane Database Syst Rev. 2015;(5):CD003343. https://doi.org/10.1002/14651858.CD003343.pub4

9. Cruz MM, Cardoso GC, Abreu DM, Decotelli PV, Chrispim PP Borenstein JS, et al. Adesão ao tratamento diretamente observado da tuberculose - o sentido atribuído pelos usuários e profissionais de saúde em duas regiões administrativas do município do Rio de Janeiro. Cad Saude Colet. 2012;20(2),217-24.

10. Brasil. Ministério da Saúde. Secretaria de Vigilância em Saúde Departamento de Vigilância Epidemiológica. Manual de recomendações para o controle da tuberculose no Brasil. Brasília: Ministério da Saúde; 2011.

11. Munro SA, Lewin SA, Smith HJ, Engel ME, Fretheim A, Volmink J. Patient adherence to tuberculosis treatment: a systematic review of qualitative research. PLoS Med. 2007:4(7):e238. https://doi. org/10.1371/journal.pmed.0040238

12. Centers for Disease Control and Prevention. Managing tuberculosis patients and improving adherence. Atlanta, GA: CDC; 2014

13. Verver $S$, Warren RM, Beyers N, Richardson M, van der Spuy $\mathrm{GD}$, Borgdorff MW, et al. Rate of reinfection tuberculosis after successful treatment is higher than rate of new tuberculosis. Am J Respir Crit Care Med. 2005;171(12):1430-5. https://doi.org/10.1164/ rccm.200409-12000C

14. Interrante JD, Haddad MB, Kim L, Gandhi NR. Exogenous Reinfection as a Cause of Late Recurrent Tuberculosis in the United States. Ann Am Thorac Soc. 2015;12(11):1619-26.

15. Ruffino Netto A. Impacto da reforma do setor saúde sobre os serviços de tuberculose no Brasil. Bol Pneumol Sanit. 1999;7(1):7-18. https://doi.org/10.5123/S0103-460X1999000100002

16. Hiijar MA, Gerhardt G, Teixeira GM, Procópio MJ. Retrospect of tuberculosis control in Brazil. Rev Saude Publica. 2007;41(Suppl 1):50-8. https://doi.org/10.1590/S0034-89102007000800008

17. Brasil. Ministério da Saúde. Sistema de Informação de Agravos de Notificação [homepage on the Internet]. Brasilia: Ministério da Saúde [cited 2016 Oct 1]. Available from: http://www2.datasus.gov. br/DATASUS/index.php?area=0203\&id=31009407\&VObj=http:// tabnet.datasus.gov.br/cgi/tabcgi.exe?sinannet/cnv/tuberc

18. Jo KW, Yoo JW, Hong Y, Lee JS, Lee SD, Kim WS, et al. Risk factors for 1-year relapse of pulmonary tuberculosis treated with a 6-month daily regimen. Respir Med. 2014;108(4):654-9. https://doi. org/10.1016/j.rmed.2014.01.010

19. Chang KC, Leung CC, Yew WW, Ho SC, Tam CM. A nested case- control study on treatment-related risk factors for early relapse of tuberculosis. Am J Respir Crit Care Med. 2004;170(10):1124-30. https://doi.org/10.1164/rccm.200407-9050C

20. Horne DJ, Royce SE, Gooze L, Narita M, Hopewell PC, Nahid P, et al. Sputum monitoring during tuberculosis treatment for predicting outcome: systematic review and meta-analysis. Lancet Infect Dis. 2010;10(6):387-94. https://doi.org/10.1016/S1473-3099(10)70071-2

21. Baker MA, Harries $A D$, Jeon $C Y$, Hart JE, Kapur $A$, Lönnroth $K$, et al. The impact of diabetes on tuberculosis treatment outcomes: a systematic review. BMC Med. 2011:9:81. https://doi. org/10.1186/1741-7015-9-81

22. Leung CC, Yew WW, Chan CK, Chang KC, Law WS, Lee SN, et al. Smoking adversely affects treatment response, outcome and relapse in tuberculosis. Eur Respir J. 2015;45(3):738-45. https://doi. org/10.1183/09031936.00114214

23. Ahmad Khan F, Minion J, Al-Motairi A, Benedetti A, Harries AD, Menzies D. An updated systematic review and meta-analysis on the treatment of active tuberculosis in patients with HIV infection. Clin Infect Dis. 2012;55(8):1154-63. https://doi.org/10.1093/cid/cis630

24. Conde MB, Melo FA, Marques AM, Cardoso NC, Pinheiro VG Dalcin Pde T, et al. III Brazilian Thoracic Association Guidelines on tuberculosis. J Bras Pneumol. 2009;35(10):1018-48. https://doi. org/10.1590/S1806-37132009001000011

25. Zvada SP, Van Der Walt JS, Smith PJ, Fourie PB, Roscigno G, Mitchison D, et al. Effects of four different meal types on the population pharmacokinetics of single-dose rifapentine in healthy male volunteers. Antimicrob Agents Chemother. 2010;54(8):3390-4 https://doi.org/10.1128/AAC.00345-10

26. Sant'Anna CC. Childhood tuberculosis. J Pediatr (Rio J). 1998;74 Suppl 1:S69-75. https://doi.org/10.2223/JPED.488

27. American Academy of Pediatrics. Committee on Infectious Diseases. 2015 Red Book: Report of the Committee on Infectious Diseases. 30th ed. Elk Grove Village, IL: AAP; 2015.

28. World Health Organization [homepage on the Internet]. Geneva: WHO [updated 2014; cited 2016 Oct 1]. Guidance for national tuberculosis programmes on the management of tuberculosis in children. 2nd ed. [Adobe Acrobat document, 146p.]. Available from: http://apps.who.int/medicinedocs/documents/s21535en/s21535en. pdf

29. World Health Organization [homepage on the Internet]. Geneva: WHO [updated 2014 Dec; cited 2016 Oct 1]. Definitions and reporting framework for tuberculosis-2013 revision. [Adobe Acrobat document, 47p.]. Available from: http://apps.who.int/iris/ bitstream/10665/79199/1/9789241505345_eng.pd

30. Brasil. Ministério da Saúde. Departamento de Vigilância em Doenças Transmissíveis. Novas recomendações para tratamento da tuberculose multidrogarresistente e com resistência à rifampicina diagnosticada por meio do Teste Rápido Molecular para Tuberculose no Brasil. Nota informativa 8. Brasília: Ministério da Saúde; 2016.

31. Conde MB, Souza MG. Pneumologia e tisiologia: uma abordagem prática. São Paulo: Atheneu; 2009

32. Maciel EL, Guidoni LM, Favero JL, Hadad DJ, Molino LP, Jonhson $\mathrm{JL}$, et al. Adverse effects of the new tuberculosis treatment regimen recommended by the Brazilian Ministry of Health. J Bras Pneumol. 2010;36(2):232-8. https://doi.org/10.1590/S180637132010000200012

33. Ferreira AC, Silva Júnior JL, Conde MB, Rabahi MF. Clinica treatment outcomes of tuberculosis treated with the basic regimen recommended by the Brazilian National Ministry of Health using fixed-dose combination tablets in the greater metropolitan area of Goiânia, Brazil. J Bras Pneumol. 2013;39(1):76-83. https://doi. org/10.1590/S1806-37132013000100011

34. Sun HY, Chen YJ, Gau CS, Chang SC, Luh KT. A prospective study of hepatitis during antituberculous treatment in Taiwanese patients and a review of the literature. J Formos Med Assoc. 2009:108(2):102-11. https://doi.org/10.1016/S0929-6646(09)60040-1

35. Singh N, Paterson DL. Mycobacterium tuberculosis infection in solidorgan transplant recipients: impact and implications for management. Clin Infect Dis. 1998;27(5):1266-77. https://doi.org/10.1086/514993

36. Chien JY, Huang RM, Wang JY, Ruan SY, Chien YJ, Yu CJ, et al. 
Hepatitis C virus infection increases hepatitis risk during antituberculosis treatment. Int J Tuberc Lung Dis. 2010;14(5):616-21.

37. Lomtadze N, Kupreishvili L, Salakaia A, Vashakidze S, Sharvadze L, Kempker RR, et al. Hepatitis $\mathrm{C}$ virus co-infection increases the risk of anti-tuberculosis drug-induced hepatotoxicity among patients with pulmonary tuberculosis. PLoS One. 2013;8(12):e83892. https://doi. org/10.1371/journal.pone.0083892

38. Combs DL, O’Brien RJ, Geiter LJ. USPHS Tuberculosis Short-Course Chemotherapy Trial 21: effectiveness, toxicity, and acceptability. The report of final results. Ann Intern Med; 1990;112(6):397-406. https:// doi.org/10.7326/0003-4819-76-3-112-6-397

39. A controlled trial of 6 months' chemotherapy in pulmonary tuberculosis. Final report: results during the 36 months after the end of chemotherapy and beyond. British Thoracic Society. Br J Dis Chest 1984;78(4):330-6. https://doi.org/10.1016/0007-0971(84)90165-7

40. Czeizel AE, Rockenbauer M, Olsen J, Sørensen HT. A populationbased case-control study of the safety of oral anti-tuberculosis drug treatment during pregnancy. Int J Tuberc Lung Dis. 2001;5(6):564-8.

41. Baghaei $P$, Marjani M, Tabarsi $P$, Moniri A, Rashidfarrokhi F, Ahmadi $F$, et al. Impact of chronic renal failure on anti-tuberculosis treatment outcomes. Int J Tuberc Lung Dis. 2014;18(3):352-6. https://doi. org/10.5588/ijtld.13.0726

42. Malone RS, Fish DN, Spiegel DM, Childs JM, Peloquin CA. The effect of hemodialysis on isoniazid, rifampin, pyrazinamide, and ethambutol. Am J Respir Crit Care Med. 1999;159(5 Pt 1):1580-4. https://doi.org/10.1164/ajrccm.159.5.9810034

43. Mack U, Migliori GB, Sester M, Rieder HL, Ehlers S, Goletti D, et al. LTBI: latent tuberculosis infection or lasting immune responses to M. tuberculosis? A TBNET consensus statement. Eur Respir J 2009;33(5):956-73. https://doi.org/10.1183/09031936.00120908

44. Getahun H, Matteelli A, Abubakar I, Aziz MA, Baddeley A, Barreira D, et al. Management of latent Mycobacterium tuberculosis infection: WHO guidelines for low tuberculosis burden countries. Eur Respir J 2015;46(6):1563-76. https://doi.org/10.1183/13993003.01245-2015

45. Brasil. Ministério da Saúde. Departamento de Vigilância Epidemiológica. Coordenação Geral de Doenças Endêmicas. Programa Nacional de Controle da Tuberculose. Plano Estratégico para o Controle da Tuberculose, Brasil 2007-2015. Brasília: Ministério da Saúde; 2006

46. Keane J, Gershon S, Wise RP, Mirabile-Levens E, Kasznica J, Schwieterman WD, et al. Tuberculosis associated with infliximab, a tumor necrosis factor alpha-neutralizing agent. N Engl J Med. 2001;345(15):1098-104. https://doi.org/10.1056/NEJMoa011110

47. Mota LM, Cruz BA, Brenol CV, Pollak DF, Pinheiro Gda R, Laurindo $\mathrm{IM}$, et al. Safe use of biological therapies for the treatment of rheumatoid arthritis and spondyloarthritides [Article in Portuguese]. Rev Bras Reumatol. 2015;55(3):281-309. https://doi.org/10.1016/j. rbr.2014.06.006

48. Wong SH, Gao Q, Tsoi KK, Wu WK, Tam LS, Lee N, et al. Effect of immunosuppressive therapy on interferon $\mathbf{c}$ release assay for latent tuberculosis screening in patients with autoimmune diseases: a systematic review and meta-analysis. Thorax. 2016;71(1):64-72. https://doi.org/10.1136/thoraxjnl-2015-207811

49. Sester M, Kampmann B. What defines latent infection with Mycobacterium tuberculosis in patients with autoimmune diseases? Thorax. 2016;71(1):3-4. https://doi.org/10.1136/ thoraxjnl-2015-207991

50. Brasil. Ministério da Saúde. Departamento de Vigilância em Doenças Transmissíveis. Recomendações para controle de contatos tratamento da infecção latente da tuberculose na indisponibilidade transitória do Derivado Proteico Purificado. Nota informativa 8. Brasília: Ministério da Saúde; 2014.

51. Piccazzo R, Paparo F, Garlaschi G. Diagnostic accuracy of chest radiography for the diagnosis of tuberculosis (TB) and its role in the detection of latent TB infection: a systematic review. J Rheumatol Suppl. 2014;91:32-40. https://doi.org/10.3899/jrheum.140100

52. Campbell J, Krot J, Marra F. Latent tuberculosis diagnostic tests to predict longitudinal tuberculosis during dialysis: a meta-analysis. Int J Tuberc Lung Dis. 2016;20(6):764-70. https://doi.org/10.5588/ ijtld. 15.0825

53. Ai JW, Ruan $\mathrm{QL}$, Liu $\mathrm{QH}$, Zhang WH. Updates on the risk factors for latent tuberculosis reactivation and their managements. Emerg Microbes Infect. 2016;5:e10. https://doi.org/10.1038/emi.2016.10

54. Sterling TR, Villarino ME, Borisov AS, Shang N, Gordin F, BlivenSizemore $\mathrm{E}$, et al. Three months of rifapentine and isoniazid for latent tuberculosis infection. N Engl J Med. 2011;365(23):2155-66. https:/ doi.org/10.1056/NEJMoa1104875

55. Villarino ME, Scott NA, Weis SE, Weiner M, Conde MB, Jones $B$, et al. Treatment for preventing tuberculosis in children and adolescents: a randomized clinical trial of a 3-month, 12-dose regimen of a combination of rifapentine and isoniazid. JAMA Pediatr. 2015;169(3):247-55. Erratum in: JAMA Pediatr. 2015;169(9):878. https://doi.org/10.1001/jamapediatrics.2014.3158

56. Marais BJ. Twelve-dose drug regimen now also an option for preventing tuberculosis in children and adolescents JAMA Pediatr. 2015;169(3):208-10. https://doi.org/10.1001/ jamapediatrics.2014.3157

57. Conde MB, Efron A, Loredo C, De Souza GR, Graça NP, Cezar MC et al. Moxifloxacin versus ethambutol in the initial treatment of tuberculosis: a double-blind, randomised, controlled phase II trial. Lancet. 2009;373(9670):1183-9. $\quad$ https://doi.org/10.1016/S01406736(09)60333-0

58. Conde MB, Mello FC, Duarte RS, Cavalcante SC, Rolla V, Dalcolmo M, et al. A Phase 2 Randomized Trial of a Rifapentine plus MoxifloxacinBased Regimen for Treatment of Pulmonary Tuberculosis. PLoS One. 2016;11(5):e0154778. https://doi.org/10.1371/journal.pone.0154778

59. Alipanah N, Cattamanchi A, Menzies R, Hopewell PC, Chaisson RE, Nahid P. Treatment of non-cavitary pulmonary tuberculosis with shortened fluoroquinolone-based regimens: a meta-analysis. Int $J$ Tuberc Lung Dis. 2016;20(11):1522-1528. https://doi.org/10.5588/ ijtld.16.0217

60. GRADE working group [homepage on the Internet]. c2004-2017 [cited 2016 Oct 1]. Available from: http://www.gradeworkinggroup. org/ 


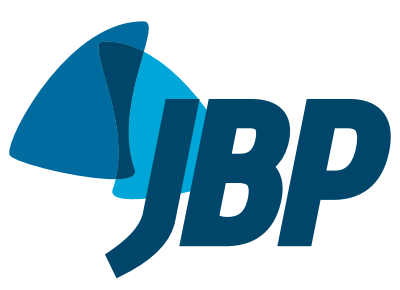

Manuscript: Tuberculosis treatment

Publication: J Bras Pneumol. 2017;43(6):472-486.

DOI: http://dx.doi.org/10.1590/s1806-37562016000000388

On page 479 , Chart 5 , where is written:

"aThe number preceding the acronym indicates duration of treatment in weeks."

\section{It should be read:}

"aThe number preceding the acronym indicates duration of treatment in months." 